\title{
DYNAMIC CONSERVATION IN AFRICA
}

\section{By E. B. Worthington}

For some years past I have had a feeling that our approach to the conservation of the flora and fauna all over the world, but especially in Africa, has been too static. This does not fit in well with the natural situations which we want to perpetuate, for they are nearly all dynamic situations. Admittedly we have moved our standpoint to some extent recently : for instance, the idea that particular species endangered by advancing civilization could survive by giving them individual protection has been generally discarded in favour of conserving the habitats in which such species live and which are prerequisites to their continued existence. But there is still much emphasis on trying to retain the status quo, say in a national park or strict natural reserve, by putting around it a real or symbolic fence and regarding the area and its ecology as sacrosanct and there for ever. And yet wherever a particular ecological situation has been studied, whether it is hinged on elephants or earthworms, the conclusion is always reached that it is dynamic-subject to continual change of balance of populations, of food relations, of chemistry and physics of the environment. Indeed nature will never stand still however much we might sometimes wish it to ; and on top of all the natural changes are others imposed by mankind.

I used to discuss this kind of thing with Captain Keith Caldwell who, as a shooting man, was interested in crops of wild species as well as stocks. Indeed, the sportsman naturalist, though to-day sometimes regarded as old-fashioned, has rather advanced ideas on conservation since the dynamics of populations are his trade. By contrast some of the new generation of naturalists who want abundance of nature for observation and have never approached it with gun or rod, sometimes adopt a more static attitude.

Perusing the pages of Oryx one finds that most writers on Africa are impressed with the diminution of the wild animal numbers and the reduction of good wild life areas as the land becomes progressively more used or abused by human kind. During some thirty years' intermittent knowledge of some of the best faunal areas I myself have been similarly impressed. Nevertheless, a two months' tour of East and Central Africa undertaken earlier this year in exercising the advisory functions of the Nature Conservancy, gave me a rather different impression. 
I had cause to wonder at the vast extent of the wild lands which still remain and are likely to do so for generations to come, and at the opportunities for applying in these wild lands the technical knowledge on the management of flora and fauna which is now available.

There are, for instance, still huge areas of tsetse fly country, estimated at a quarter of the whole Continent, still denied to domestic animals unless aided by drugs. The fringes of this vast tract are tending to be used for agriculture or animal husbandry, sometimes to the detriment of its soils; but there is no likelihood of an early and general invasion of the tsetse strongholds by human kind. Meanwhile the potential (though not the actual) productive capacity of the tsetse country-the sustained yield of wild plant and animal products which could be made available for human purposes if proper systems of management were applied-is relatively enormous. Equally large areas exist where the climate is so dry and vegetation so thin that they cannot provide either shelter for tsetse flies or fodder for domestic animals, but nevertheless happen to be the habitats in which a number of species of hoofed mammals have evolved, and where they would abound to-day to the great benefit of human beings, if only it were possible to apply sensible management.

It is in such areas, classified as poor or marginal by agriculturalists that opportunities are greatest for conservation through the wise use of nature as an economic resource, rather than in those which have a high capacity to produce domesticated plants and animals or timber. Although the wild animals in such areas have generally been grossly overcropped and the remaining stocks are in no condition to produce anything like a maximum sustained offtake, the resilience of the wild habitats and their animal inhabitants is such that the position is by no means hopeless.

But the proper utilization of wild lands presupposes a solution to the human problem. In other words there needs to be a general realization of the value of wild life as an economic resource and as a cultural asset. In addition there needs to be a comprehensive system of control, and a measure of self-discipline among those privileged to take the crop.

At the present time there would seem to be special opportunities for turning the wild resource to economic account in buffer zones surrounding national parks, some of which are now tending to become overstocked with certain species of animals. An idealized pattern of land use would be : 
(1) one or more "Strict Natural Reserves", in the sense of the International Convention for the Preservation of the Flora and Fauna of Africa of 1933, maintained for scientific study under conditions of no interference with natural processes. These natural reserves, not necessarily very large in area, would be situated within

(2) a National Park which is managed to provide a maximum carrying capacity for wild animals and maximum attraction to tourists ;

(3) a buffer zone surrounding the National Park would likewise be managed but with an eye to a maximum sustained yield of wild animals, derived from the buffer zone itself and from the overflow from the National Park. It would be cropped by legalized hunters ;

(4) surrounding the buffer zone would be settled areas of agriculture in which those kinds of wild animals which cause damage would be strongly discouraged.

Apart from the special opportunity of cropping wild life in buffer zones surrounding National Parks, the possibilities of applying conservation measures in hunting areas to bring back stocks to a point at which they could sustain a regular yield has been a recurrent theme at wild life discussions, certainly since the first East and Central African Wild Life Conference of 1947. It was the reason for introducing the system of "Controlled areas" started in Northern Rhodesia and now adopted in most territories. Although the management of controlled areas has been and still is somewhat crude, it is based on the sound principle of making estimates of the stock of different species and limiting the annual crop to a total which is thought to be not more than the annual increase.

During the past few years the ecological principles behind this kind of management have been studied and elucidated by the few biologists employed in the departments, by a succession of Fulbright Fellows who have studied particular situations, especially in Uganda and Southern Rhodesia, and by visiting scientists such as Dr. F. Fraser Darling who has examined the situation in Northern Rhodesia and part of Kenya, and Professor W. H. Pearsall who examined the Serengeti area of Tanganyika. In addition, unofficial organizations, such as the Kenya Wild Life Society, have done much to illustrate how the principles involved might be turned to economic account and at the same time to fulfil the purpose of conserving wild life in areas where it still persists. 
There are good theoretical arguments for claiming that in marginal and poor lands the potential productive capacity of the indigenous fauna of Africa is probably as high as that of domestic animals, all of which have been introduced from other continents. The wild flora usually comprises herb layer, shrub layer and trees and these are utilized by a dozen or more species of animals from pigs rooting underground to giraffes feeding on the treetops, with a range of grazers and browsers in between.

More important perhaps than the theoretical arguments, firm data are now emerging from various parts of the Continent to show that specified areas actually carry stocks of wild animals and are capable of producing crops which are surprisingly large in relation to the habitats which support them. In some cases such proved stocks are well in excess of the stock of domestic animals which any specialist in ranching would consider appropriate. Some of these data have come from national parks, others from game reserves or controlled hunting areas, and some from country which had formerly been given over to ranching.

A few of the national parks are now mature enough to illustrate the effect of protection on stocks of animals, and the influence of increased animal numbers on the habitat. In certain cases it has been shown beyond doubt that overstocking with large animals like elephants and hippopotami, which are not subject to control by predators as are the antelopes and zebra, is having a deleterious effect. In such cases a system of cropping has become an essential part of management even within a national park. More often the studies suggest that a game cropping scheme in an area adjacent to a national park could not only produce large quantities of animal protein from the overflow from heavily stocked areas, but could also act as the best form of buffer zone for the park itself.

One can carry forward this idea in theory, though not yet in practice, to envisage a series of animal cropping schemes which could have a pronounced social as well as economic influence. In general the cropping would be carried out by properly supervised African hunters who are accustomed to that way of life and who in the absence of any legal outlet for their activities, continue to cause a great deal of trouble to the authorities through poaching on the fringe areas if not inside the national parks.

The points at issue could be illustrated by reference to a few examples some of which have been described in recent numbers of Oryx. One thinks, for instance, of the Galana River Scheme 
in Kenya, where elephants are now being cropped in a large buffer zone outside the Tsavo National Park; of hippos in Uganda where, following the experimental culling operation in the Queen Elizabeth National Park, a carefully-planned hippo cropping and marketing scheme is now being put into operation in adjacent areas outside the Park. The Serengeti country of Tanganyika, comprising the Conservation Unit and the National Park offers perhaps the best opportunity which has yet occurred in Africa for getting to grips with the dynamics of conservation : the team of six specialist officers and their assistants in the Conservation Unit are able collectively to look at all major subjects which contribute to the ecological complex of a pastoral and wild life area; while the National Park is likewise being subjected to a new scrutiny. A much smaller area in the same country-the new Ngurdoto Crater National Park-is the best example I know of a substantial and varied population of mammals seemingly in balance with the habitat of forest, grassland and swamp, and as such it will certainly repay close study. The red lechwe of the Kafue plains in Northern Rhodesia, having been reduced in numbers to about a tenth of their original abundance through wanton slaughter, are simply asking for a dynamic conservation programme so that they could be allowed to increase their stocks again and yield up to say 25,000 carcasses per annum for the benefit of the local people. Finally, in Southern Rhodesia we have the striking work of two American Fulbright Fellows who, after detailed study, have persuaded not only themselves but also the owners of several large ranches that from certain types of habitat a higher economic and financial return could be obtained from wild than domesticated animals.

Examples such as these illustrate the new ecological thinking and study which is now going on in Africa. They raise questions of economics of wild lands which need to be married with other questions relating to the tourist industry as well as to the cultural and prestige value of wild life. Most of this thinking is at present in the heads of white men. But here and there are indigenous Africans who are contributing to these ideas, and are prepared to spread the news to their colleagues. It is with the object of greatly increasing their numbers-indeed, the numbers of all races in Africa who, in the interests of their own future, are enthusiasts for conservation-that the Africa Special Project of I.U.C.N., noticed elsewhere in this issue, has been launched. 